\title{
Modulation of dopamine release by $\alpha 7$-type nicotinic acetylcholine receptors
}

\author{
Reinoud Maex ${ }^{1 *}$, Vladimir Grinevich², Evgeny Budygin ${ }^{3}$, Merouane Bencherif ${ }^{4}$, Boris Gutkin ${ }^{1}$ \\ From Twenty Second Annual Computational Neuroscience Meeting: CNS*2013 \\ Paris, France. 13-18 July 2013
}

Disentangling receptor kinetics and network dynamics is a prerequisite for understanding and predicting the systemic effects of pharmacological compounds. These effects may result from a complex balance between activation and desensitization of various receptor subtypes that can be located on excitatory or inhibitory neurons or their afferent fibres. We therefore combined receptor and network modelling [1] to explain the suppressive effect that TC-7020 [2,3], a partial agonist of $\alpha 7$-type nicotinic acetylcholine receptors ( $\mathrm{nAChRs),} \mathrm{was} \mathrm{observed} \mathrm{to} \mathrm{exert}$ on the release of dopamine (DA) in the nucleus accumbens of anesthetized rats. As nAChRs are ion channels permeating $\mathrm{Na}^{+}$and $\mathrm{Ca}^{2+}$, and as i.v. injection of nicotine itself enhanced DA release, partial agonists would rather be expected to enhance DA release as well.

Using the model, we evaluated several potential effects of TC-7020 on DA-ergic and GABA-ergic neurons in the ventral tegmental area (VTA) and its glutamatergic afferents from neocortex. Potential effects of TC-7020 included on the one hand a reduced $\mathrm{nAChR}$ channel conductance on DA neurons through competitive or non-competitive inhibition, or through receptor desensitization. On the other hand, enhancing the $\mathrm{nAChR}$ conductance on GABA-neurons (through direct activation of nAChRs, or through priming of their response to background ACh [4]) could have produced, through inhibition of DA neurons, a similar suppressive effect on DA release. The model showed that rapid desensitization of the $\alpha 7 \mathrm{nAChRs}$ on DA neurons explained both the sign and time-course of the voltammetric DA response, provided that a background cholinergic tone was present that contributed, by activating $\alpha 7 \mathrm{nAChRs}$ without desensitizing them, to the baseline level of DA release.

\footnotetext{
* Correspondence: Reinoud.Maex@ens.fr

${ }^{1}$ Department of Cognitive Sciences, École Normale Supérieure, Paris 75005, France

Full list of author information is available at the end of the article
}

Another surprising finding of the voltammetric DA recordings was that PNU-120596, a positive allosteric modulator of $\alpha 7 \mathrm{nAChRs}$, prevented and abolished the effect of TC-7020 on DA release, instead of amplifying it. The model proposes two possible but contrasting mechanisms: a well-established relieve of $\alpha 7 \mathrm{nAChRs}$ from the weak state of desensitization into which they were brought by TC-7020, or, in contrast, the induction of a strong desensitization in $\alpha 7 \mathrm{nAChRs}$ due to channel over-excitation by background ACh under the amplifying effect of PNU-120596 [5].

These results show that tonic levels of neurotransmitters and neuromodulators like acetylcholine and dopamine may profoundly affect the dynamics, and hence the systemic effect, of pharmacological compounds. As these background levels may be altered in in-vitro preparations, circuit modelling may become an indispensible tool in drug development.

\section{Author details}

${ }^{1}$ Department of Cognitive Sciences, École Normale Supérieure, Paris 75005, France. ${ }^{2}$ PET Center, Wake Forest Baptist Medical Center, Winston-Salem, NC 27157, USA. ${ }^{3}$ Department of Neurobiology \& Anatomy, Wake Forest Baptist Medical Center, Winston-Salem, NC 27157, USA. ${ }^{4}$ Targacept Inc., WinstonSalem, NC 27101, USA.

Published: 8 July 2013

\section{References}

1. Graupner M, Gutkin B: Modeling nicotinic neuromodulation from global functional and network levels to $\mathrm{nAChR}$ based mechanisms. Acta Pharmacol Sin 2009, 30:681-693.

2. Marrero MB, Lucas R, Salet C, Hauser TA, Mazurov A, Lippiello PM, Bencherif $M$ : An a7 nicotinic acetylcholine receptor-selective agonist reduces weight gain and metabolic changes in a mouse model of diabetes. J Pharmacol Exp Ther 2010, 332:173-180.

3. Kucinski A, Syposs C, Wersinger S, Bencherif M, Stachowiak MK, Stachowiak EK: a7 neuronal nicotinic receptor agonist (TC-7020) reverses increased striatal dopamine release during acoustic PPI testing in a transgenic mouse model of schizophrenia. Schizophr Res 2012, 136:82-87.
() Biomed Cental

(c) 2013 Maex et al; licensee BioMed Central Ltd. This is an Open Access article distributed under the terms of the Creative Commons Attribution License (http://creativecommons.org/licenses/by/2.0), which permits unrestricted use, distribution, and reproduction in any medium, provided the original work is properly cited. 
4. Zwart R, Vijverberg HP: Potentiation and inhibition of neuronal nicotinic receptors by atropine: competitive and noncompetitive effects. $\mathrm{Mol}$ Pharmacol 1997, 52:886-895.

5. Williams DK, Wang J, Papke RL: Investigation of the molecular mechanism of the a7 nicotinic acetylcholine receptor positive allosteric modulator PNU-120596 provides evidence for two distinct desensitized states. Mol Pharmacol 2011, 80:1013-1032.

doi:10.1186/1471-2202-14-S1-P155

Cite this article as: Maex et al:: Modulation of dopamine release by $\alpha 7$-type nicotinic acetylcholine receptors. BMC Neuroscience 2013 14(Suppl 1):P155

Submit your next manuscript to BioMed Central and take full advantage of:

- Convenient online submission

- Thorough peer review

- No space constraints or color figure charges

- Immediate publication on acceptance

- Inclusion in PubMed, CAS, Scopus and Google Scholar

- Research which is freely available for redistribution

Submit your manuscript at www.biomedcentral.com/submit
C Biomed Central 